\title{
Managing Oaks to Produce Food for Wildlife ${ }^{1}$
}

\section{Holly K. Ober and Patrick J. Minogue ${ }^{2}$}

Florida is home to many species of oaks that vary greatly in overall size and form, longevity, and the growing conditions in which they thrive (Figure 1). Oaks grow in a variety of locations, ranging from the sandy, excessively drained soils of the Florida Sand Ridge to the poorly drained soils of alluvial bottoms. Individual oak species are adapted to different growing conditions.

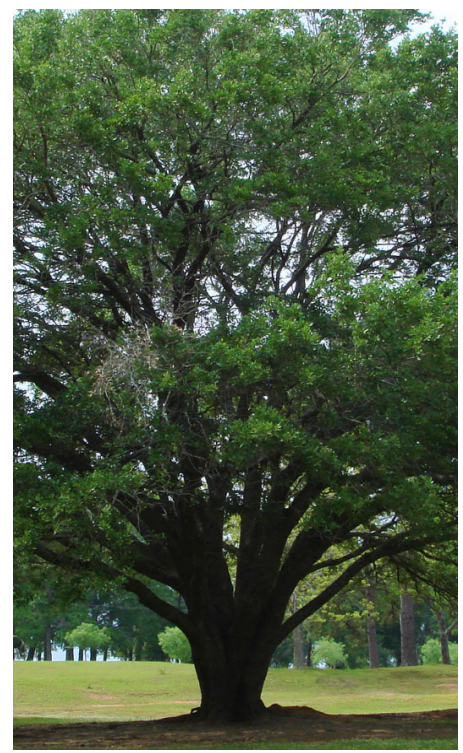

Figure 1. Live oaks can be found throughout Florida under a variety of growing conditions. Credits: Holly Ober, 2008
There are many reasons landowners with an interest in wildlife should consider establishing or maintaining oaks on their property. The most compelling reason is that they produce acorns, which are an important food source for animals. Species such as white-tailed deer, gray squirrels, fox squirrels, flying squirrels, mice, voles, rabbits, raccoons, opossums, gray foxes, red foxes, wild hogs, wild turkey, bobwhite quail, wood ducks, mallards, woodpeckers, crows, and jays eat acorns (http://edis.ifas.ufl.edu/UW292).

Landowners can increase the survival and reproduction of many animal species by providing a steady supply of acorns (figure 2). This is because acorns become available during the time of year when many other foods are in short supply (fall and winter). The presence of acorns can reduce food stress and increase overall animal well-being, which in turn increases their resistance to disease and parasites. Abundant acorns can reduce the amount of time animals need to search for food, decreasing vulnerability to predators. Large acorn supplies can also decrease the distance of daily animal movements and decrease the likelihood that animals will embark on long distance movements away from your property. The abundance of acorns one year can even

1. This document is WEC249, one of a series of the Wildlife Ecology and Conservation Department, Florida Cooperative Extension Service, Institute of Food and Agricultural Sciences, University of Florida. Original publication date August 2008. Visit the EDIS Web site at http://edis.ifas.ufl.edu.

2. Holly K. Ober, assistant professor and extension specialist, Department of Wildlife Ecology and Conservation; and Patrick J. Minogue, assistant professor and extension specialist, School of Forest Resources and Conservation, University of Florida, IFAS at the North Florida Research and Education Center, 155 Research Road, Quincy, Florida 32351

The Institute of Food and Agricultural Sciences (IFAS) is an Equal Opportunity Institution authorized to provide research, educational information and other services only to individuals and institutions that function with non-discrimination with respect to race, creed, color, religion, age, disability, sex, sexual orientation, marital status, national origin, political opinions or affiliations. U.S. Department of Agriculture, Cooperative Extension Service, University of Florida, IFAS, Florida A. \& M. University Cooperative Extension Program, and Boards of County Commissioners Cooperating. Larry Arrington, Dean 
affect the reproductive success of animals the following year.

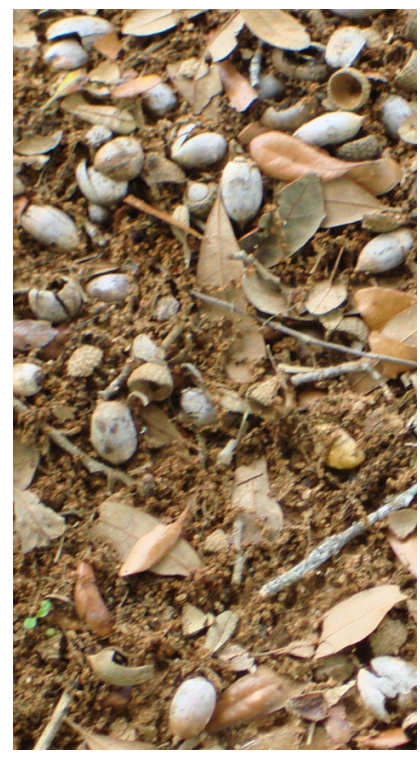

Figure 2. Acorns are a valuable source of food for many species of wildlife. Credits: Holly Ober, 2008

Another reason landowners might consider planting oaks is to reduce foraging pressure on other plants. In areas where deer browsing of agricultural crops or ornamental plants is problematic, the addition of oaks may reduce the problem by providing animals with an alternative food source.

\section{Oaks Found in Florida}

See tables 1 and 2 for a list of the oak species of Florida, and see http://edis.ifas.ufl.edu/FR004 for information on how to identify each species.

When managing oak trees for the purpose of providing benefits to wildlife, it is important to recognize that many differences exist among oak species. First, oaks of different species produce acorns that vary in nutritional quality (http://edis.ifas.ufl.edu/UW292). Second, oak species differ in the timing of acorn production, with acorns from trees in the white oak group being available for shorter periods of time than acorns from the red oak group. Third, species differ in the quantity of acorns produced (see Table 3). Finally, only those species that are adapted to the region and to the specific growing conditions of a site will thrive and produce large quantities of acorns. For these reasons it is important that landowners interested in promoting wildlife establish a variety of oak species, with representative trees that produce acorns at different times, and to plant species adapted to the conditions of the site. This will increase the likelihood that food will be available each year, that food will be available for long periods of time within each year, and that food will be available in large quantities.

\section{Establishing New Oak Trees}

Landowners and land managers with large acreages should consider retaining or establishing oaks in both bottomland and upland sites. The activity of some wildlife species, such as wood ducks, is restricted to wet lowland areas, and streamside areas in bottomlands are frequently used by many wildlife species as travel corridors. Furthermore, the rich soils characteristic of these areas tend to produce large trees, and large trees can in turn produce large acorn crops for wildlife. On the other hand, species such as squirrels and rabbits are more common in upland sites. Upland areas planted with pine monocultures generally provide limited food sources for wildlife. By providing oaks in upland areas near pine plantations, land managers introduce both food and cover options for animals.

Overall animal species diversity can be increased in an area when acorns are available in both upland and bottomland habitats. By maintaining well-distributed and abundant food and cover sources throughout their property, landowners allow animals to better meet their needs within a relatively small space. This decreases the likelihood that animals will move to adjacent properties.

Choosing the correct oak species for a site is critical to success in establishing oaks (Tables 1 and 2). Some oak species thrive in wet bottomland soils (overcup, swamp chestnut, diamond-leaf, cherrybark, shumard, and willow oak), whereas others are suited to drier, upland soils (blackjack, bluejack, Chapman, turkey, and live oaks), and still others are adapted to both bottomland and upland sites (water, southern red, post oak).

Oaks are relatively difficult to establish by artificial means but readily reproduce from stump or root sprouts. Planting seedlings is more likely to lead to successful establishment of new oaks than is 
sowing acorns. On dry, upland sites, use

containerized planting stock. A key to obtaining good survival with oaks is to use seedlings with large stem diameters (1 inch or greater). Plant seedlings during the winter when the soil is moist. Various browse guards can be used to protect seedlings from injury resulting from animal browsing. A small amount (1/4 cup) of granular fertilizer such as 10-10-10 may be applied around the base of each seedling in early spring. Newly established oaks are sensitive to competition, so if grasses are abundant, prepare the site with an herbicide such as glyphosate (Roundup®, Accord $\AA$ XRT II) in the growing season before planting. Treat a five-foot-diameter circle and mark the center where the seedling will be planted with a wire flag.

During the establishment period, which may last from 1 to 3 years, the above-ground portions of many planted seedlings tend to die back, sometimes to ground-line, while the root system is developing. This dieback often occurs during periods of dry weather or winter months (in north Florida) and is most common on upland sites. Should dieback occur, new shoots normally emerge from the green stem or root collar, and when the root system is adequate to support top growth, the seedlings will start to grow normally. Oaks grow very slowly when they are young, particularly if they are shaded.

Oaks are generally not shade-tolerant. When establishing oaks in an existing forest, seedlings should be planted where there is adequate sunlight to support their growth. Large openings in the forest canopy ( 50 feet across or more) caused by natural tree mortality or the intentional cutting of less desirable species make ideal planting sites. In areas where few or no oaks currently exist, establishment of approximately five oaks per acre is recommended to provide food for wildlife. Even with the best care at least five seedlings should be planted for each mature, acorn-producing oak desired, because several may die and several others may never produce large crops of acorns.

\section{Habitat Improvement in Established Oak and Mixed Hardwood Stands}

Acorn production varies not only among species of oaks, but also among trees within a single species. Healthy oaks with room to grow generally produce more acorns. In areas where oaks are present in greater densities than desired, it is wise to determine which individual trees consistently produce the greatest yield of acorns. Retain these trees and harvest the poor acorn producers. Removing the poor acorn producers will likely increase acorn production in the remaining trees.

The number of acorns a tree produces is influenced by many factors, including weather patterns, soil characteristics, density of overstory trees, the presence of disease and insects, and characteristics of the tree itself, such as age, size, crown area, and genetics. Trees should be monitored for several years to determine which consistently produce high acorn yields. Each year, use binoculars to inspect tree crowns before acorns begin to drop, and classify the trees as either above or below average acorn producers. Mark good acorn producers each year, and target for harvest only those trees that consistently produce below average yields. Individual oaks generally have large crops at irregular intervals, spanning from 2 to 10 years, so it is important to monitor acorn production for a minimum of 3 to 5 years before deciding which trees to harvest.

As a general rule, acorn yields increase as trees age, up until the point in time where portions of the trees begin to die. Also, a greater proportion of large trees produce acorns than small trees. Both of these reasons may tempt landowners to remove smaller, younger trees to hasten the growth and reduce competition for larger, older trees. It is important to remember, however, that some trees of younger age classes will be needed to replace older trees as the older ones die. If all oaks are of the same older age class, there may be a long period of time with low acorn availability when older trees have died and younger trees are not yet producing good crops.

Some oaks respond positively to fertilization, whereas others do not. Fertilization may increase diameter or height growth, and under certain 
conditions it may increase acorn production. However, the response of individual trees to fertilization is variable, so time and money is probably better spent on other habitat improvements rather than on oak fertilization.

Most native oaks do not begin producing significant acorn crops until they reach about 20 years of age. Therefore, oak management should be viewed as a long-term investment in habitat improvement for wildlife. Sawtooth oak (Quercus acutissima), a non-native species originally from Asia, was once recommended to landowners interested in increasing mast availability in the southeastern United States because it produces acorns at a much younger age than most oak species native to the region. However, given the short period of availability of acorns from this exotic species and the multitude of native oak species available in Florida, planting a variety of native species of oaks is considered a superior alternative to planting sawtooth oaks.

\section{Additional information}

Arny, N. P. Common oaks of Florida. University of Florida, IFAS Extension document FOR 51 available at http://edis.ifas.ufl.edu/FR004.

Byrd, N. A. and H. L. Holbrook. 1974. How to improve forest game habitat. Forest Management Bulletin. USDA Forest Service, 1720 Peachtree Road, NW, Atlanta, GA 30309. 6 pp.

Demers, C. Long, A., and Latt, C. Establishing and maintaining wildlife food sources. University of Florida, IFAS Extension document SS-FOR-12 available at http://edis.ifas.ufl.edu/FR062.

McShea, W. J., and Healy, W. H. 2002. Oak Forest Ecosystems: Ecology and Management for Wildlife. John Hopkins University Press, Baltimore, MD.

Ober, H. K. The value of oaks to wildlife. University of Florida, IFAS Extension document WEC248 available at http://edis.ifas.ufl.edu/UW292.

Schaefer, J.M., Cohen, J. and Hostetler, M. The wood duck. University of Florida, IFAS Extension document WEC168 available at http://edis.ifas.ufl.edu/UW180.
Sekerak, C.M., and Tanner, G.W. Making the most of your mast. University of Florida, IFAS Extension document available at http://www.sfrc.ufl.edu/Extension/pubtxt/ssfor3.htm. 
Table 1. Name, distribution, and habitat characteristics for species in the white oak group.

\begin{tabular}{|c|c|c|c|}
\hline Common name & Latin name & Natural range in FL & Habitat associations \\
\hline Bluff oak & Quercus austrina & NW, NE, Central & slopes, ravines, and bluffs \\
\hline Chapman (scrub) oak & Q. chapmanii & NW, NE, Central, S & $\begin{array}{l}\text { dry, sandy, ridges; coastal dune scrub; } \\
\text { pine-oak scrub }\end{array}$ \\
\hline Chinkapin (yellow chestnut) oak & Q. muehlenbergii & NW & bluffs; rocky slopes \\
\hline Live (southern live) oak & Q. virginiana & NW, NE, Central, S & wide variety of soils \\
\hline Overcup (swamp post) oak & Q. lyrata & NW, NE & lowlands and floodplains \\
\hline Post (iron) oak & Q. stellata & NW, NE, Central & uplands; sandy soils; mixed hardwoods \\
\hline Sand live oak & Q. geminata & NW, NE, Central, S & coastal dune scrub; pine-oak scrub \\
\hline Sand post (dwarf post) oak & Q. margaretta & NW, NE, Central & dry, sandy, ridges; pine-oak scrub \\
\hline Swamp chestnut (cow, basket) oak & Q. michauxii & NW, NE, Central & $\begin{array}{l}\text { lowlands and floodplains; slopes of } \\
\text { ravines and bluffs }\end{array}$ \\
\hline White oak & Q. alba & NW & Well-drained soils; hardwood forests \\
\hline
\end{tabular}

Table 2. Name, distribution, and habitat characteristics for species in the red oak group.

\begin{tabular}{|l|l|l|l|}
\hline \multicolumn{1}{|c|}{ Common name } & \multicolumn{1}{c|}{ Latin name } & \multicolumn{1}{c|}{ Natural range in FL } & \multicolumn{1}{c|}{ Habitat associations } \\
\hline Black (yellow-barked) oak & Quercus velutina & NW & uplands; mixed woodlands \\
\hline Blackjack oak & Q. marilandica & NW & clay soils \\
\hline Bluejack (sand) oak & Q. incana & NW, NE, Central & dry, sandy ridges \\
\hline Diamond-leaf (laurel) oak & Q. laurifolia & NW, NE, Central, S & lowlands and floodplains \\
\hline Laurel (diamond-leaf) oak & Q. hemisphaerica & NW, NE, Central, S & mixed woodlands; sandy ridges \\
\hline Myrtle oak & Q. myrtifolia & NW, NE, Central, S & dry, sandy ridges; coastal dune scrub \\
\hline Runner (running) oak & Q. pumila & NW, NE, Central, S & dry, sandy ridges \\
\hline Scrub (sandhill) oak & Q. inopina & C & sand pine scrub; scrubby flatwoods \\
\hline Shumard (swamp) oak & Q. shumardii & NW, NE, Central & moist soils near streams or swamps \\
\hline Southern red (Spanish) oak & Q. falcata & NW, NE, Central & dry, sandy uplands \\
\hline Swamp red (cherrybark) oak & Q. pagoda & NW & floodplains \\
\hline Turkey oak & Q. laevis & NW, NE, Central & dry, sandy ridges \\
\hline Water (spotted) oak & Q. nigra & NW, NE, Central, S & moist uplands; lowlands and floodplains \\
\hline Willow oak & Q. phellos & NW, NE & lowlands and floodplains \\
\hline
\end{tabular}

Table 3. Expected acorn yields of several species of oaks with different diameters. Diameter at breast height (DBH) is measured in inches, basal area (BA) in square feet, and acorn yields in pounds (after being air dried). Adapted from Byrd and Holbrook, 1974.

\begin{tabular}{|c|l|l|l|l|l|}
\hline DBH $^{\mathbf{1}}$ & \multicolumn{1}{|c|}{ BA $^{\mathbf{2}}$} & \multicolumn{1}{|c|}{ Chestnut oak } & \multicolumn{1}{|c|}{ White oak } & \multicolumn{1}{c|}{ Southern red oak } & Water oak \\
\hline 10 & 0.55 & 1.8 & 1.3 & 0.6 & 0.8 \\
\hline 16 & 1.40 & 4.5 & 3.1 & 2.0 & 5.1 \\
\hline 20 & 2.19 & 4.0 & 4.8 & 3.6 & 4.0 \\
\hline 24 & 3.14 & 3.2 & 5.8 & 3.8 \\
\hline
\end{tabular}

${ }^{1}$ Diameter at breast height $(\mathrm{DBH})$ is the tree diameter at 4.5 feet from the ground, used to measure tree size.

${ }^{2} \mathrm{Basal}$ area (BA) is the cross-sectional area of stems at 4.5 feet from the ground, used to measure tree density. 